\title{
DESIRE IN TRANSLATION: WHITE MASCULINITY AND TESOL IN JAPAN
}

\section{Abstract}

This article reports on a study of Western male English language teachers in Japan and considers the ways in which their identities were shaped in relation to discourses of masculinity and heterosexuality. The article first argues that masculinity and heterosexuality have remained unmarked categories in research on TESOL teacher identities. It then draws on interview data with eleven white Australian men and considers the discourses of gender and sexuality in their accounts of English language teaching in Japanese commercial eikaiwa (English language conversation schools). The analysis suggests that while some enjoy the privileges that attach to the white, Western male body, they also struggle to negotiate the eikaiwa as a contact zone where the professional and personal, the educational and commercial, the pedagogical and the sexual, co-exist. In this ambiguous space, discourses of white male embodiment, and of sexualised desire between teacher and student, are perceived to be in conflict with discourses of an acceptable masculine professional identity, and may limit the professional and pedagogical aspirations of the male teachers. The article concludes that it is timely for conversations about gender and sexuality as aspects of professional identity to include accounts of masculinity and heterosexuality as integral to professional practice in TESOL.

\section{INTRODUCTION}

Ben: in Osaka, we had a contest around Valentine's Day, who could cover their desk in chocolate the fastest.

Ros: this was a contest amongst the men?

Ben: yes, the women had a duty to buy chocolate for the men.

Ros: was that a Japanese custom? 
Ben: yes, the idea was to cover your desk with chocolate, because you could. So you'd try to curry favour with the students, but that wasn't difficult because basically you were just yourself and they liked you. It wasn't difficult. You were polite, you were friendly, but you were- they were- um, quite- friendly. Um, and I guess it was a question of being more expressive, being more attentive, being more um, complimentary um, in a normal way, nothing over the top, um, and they responded to it.

Ros: you mean as a Western man?

Ben: $m m$, as opposed to what they were used to which was grunts, and being ignored, and um, being shouted at, being told what to do.

Ben, a Caucasian Australian, is relaying to me his experiences as a white Western ${ }^{1}$ male English language teacher in Japan and, in doing so, opens the window onto a dynamic scene in which gender, sexuality and intercultural desire converge as potent forces in language teaching as a global profession. In Ben's account of Valentine's Day, we glimpse an array of participants, both Western and Japanese, male and female, and begin to sense something of the complex competitive drives and contrasting representations of masculinity and heterosexuality at play in a specific site of English language teaching. This article presents the interview accounts of Ben and ten other Australian male language teachers as they reflect on their experiences of teaching EFL in Japan, and their perceptions of practices in Japanese commercial eikaiwa: private, for-profit, conversation schools situated throughout Japan that cater to a largely female clientele, and employ significant numbers of native-English-speaking teachers for classroom and individual tuition (Bailey, 2006, 2007; Kubota, 2011). In so doing, the article provides an insight into contextually-specific constructions of masculine identity in ELT, an aspect of gender dynamics that has received little attention in studies of gender and TESOL as an intercultural domain.

\footnotetext{
${ }^{1}$ I acknowledge that 'white' and 'Western' are complex and contentious categorisations, but have adopted these as the terms most commonly used by the study participants to refer to themselves and their colleagues.
} 
A serious interest in gender (primarily dealing with women's experience) and race has been evident in TESOL research over recent years. TESOL Quarterly special issues on gender (2004) and race (2006), and related articles on sexuality (primarily dealing with gay and lesbian identities), have contributed to our understanding of the ways in which these aspects of identity are constituted in relation to language learning and teaching. In the special issue on gender, the two articles that focused on teachers' gender (Lin, Grant, Kubota, Motha, TinkerSachs, Vandrick, \& Wong, 2004; Simon-Maeda, 2004) draw on women's lived experience and situate this within broader social discourses to argue that women EFL educators are subject to discrimination and positioned unfavourably in the gender and racial hierarchies operating with the TESOL profession. In particular, Simon-Maeda (2004) argues that "women EFL educators remain in disadvantaged positions within Japanese higher education" as a "maledominated work situation" (p. 409-410), and more broadly within "conventional gender ideologies in Japan" that privilege "male professionals" (p. 415). What remains unexamined, however, is an understanding of the ways in which Western male identities are experienced, within EFL education, either in Japan or elsewhere.

The purpose of this article, then, is twofold. First, it argues that masculinity and heterosexuality have remained unmarked categories in research on TESOL teacher identities, and suggests that further research is warranted to build a broader picture of the ways in which masculinity is produced and experienced in EFL as a global industry. Second, it aims to open a scholarly conversation by providing a first step towards addressing this absence: presenting an empirical study based on the experiences of Australian male English language teachers in 
Japan, the home of a major EFL industry. Although this study is necessarily partial and localised, as is any study of identity, it contributes to the growing body of research into ELT professional identities and extends understandings of gender and sexuality in the intercultural world of TESOL.

\section{MASCULINITY AND HETEROSEXUALITY AS UNMARKED CATEGORIES IN TESOL}

To date, studies of gendered identity in ELT have primarily focused on the experiences of women teachers, while studies of men and masculinity in this field are rare. Although men have published research on most aspects of language teaching and learning, and several recent volumes on English language and ELT in Japan have been published by white Western men (Kiernan, 2010; McVeigh, 2002; Seargeant, 2009, 2011), men's personal reflections as gendered participants in professional practice have been sadly missing (Davis \& SkiltonSylvester, 2004). This is perhaps understandable since, in many locations, women outnumber men in the language teaching profession. But it could equally be argued that the invisibility of men, their position as the unmarked category in TESOL, serves to perpetuate an assumed "patriarchal" gender hierarchy that privileges, at least discursively, "the Western male academy" and "male academics" over "female teachers and language classrooms" (Pennycook, 1989, p. 612; see also Lin et al., 2004, p. 495-6). If we take seriously the notion that classrooms always operate in the context of broader social, economic, and political domains, then the connections between pedagogical masculinities - that is, the experiences of men as classroom teachers - and gender relations in TESOL and in society at large, are worthy of investigation. 
Research in TESOL has also been concerned with the ways in which race and/or ethnicity are manifest as social categories in the construction of ELT identities. As Kubota and Lin (2006) point out in their introduction to the TESOL Quarterly special issue on race, professional practice in our field inevitably involves groups of people who are "perceived as racially and culturally distinct" (p. 472) and, given the history of ELT, it is not surprising that several studies in the special issue focus on the significance and experience of whiteness, and the positionality of white teachers and researchers. However, although it is widely recognised that "the idea of race intersects with gender and sexuality in identity construction and negotiation" (Kubota \& Lin, 2006, p. 480), studies that focus on the intersection of gender and race are predominantly authored by, and focus on, experiential and narrative accounts of women teachers and researchers. While this is not necessarily a shortcoming, and may indeed be said to rectify an absence of female researcher voices in TESOL, it does raise questions about the absence of male teachers writing about their own experiences and positionality as white men in TESOL classroom practice.

Heterosexuality has also been an unmarked category in TESOL research and, as such, has received little explicit attention (Davis \& Skilton-Sylvester, 2004). Yet, as Cameron and Kulick (2003) observe, sexual identities and practices are significant in shaping performances of gender, and many performances of gender will involve the affirmation of heterosexual identity "because of the heteronormative assumption that heterosexuality is an indispensible element of 'proper' femininity or masculinity" (p.73). The absence of studies that explore heterosexuality in TESOL might be explained by the difficult, and often taboo, nature of sexuality in the classroom, where "relationships between male 
teachers and female students are sexualized as harassment" (Gallop, 1995, p. 81). And yet research on education outside of the TESOL field suggests that the frisson of eroticised attraction that can emerge within the pedagogical relationship is a significant experience for some teachers and students (see, for example, Gallop, 1995; T.S. Johnson, 2006; Sikes, 2006). This article takes up the difficult question of teacher-student heterosexual attraction, the taboo issue that simmers on the edge of Ben's account of Valentine's Day, as a topic that is worthy of investigation within the domain of gender and TESOL.

From the above, it is evident that any exploration of masculinity and heterosexuality in TESOL needs to engage with the notion that gender and sexuality are always relational. In this regard, I draw on Cameron's (2005) observation that heterosexual masculinity is not only about relations between men and women, but also about relations of status and prestige among men. Thus, Ben's Valentine's Day account highlights the way masculinity is constituted in the relationship between male teachers and female students, and between Japanese women and Japanese men (who are implicitly men who "grunt" and "shout"); but it also indicates the construction of masculinity through a competitive relationship amongst Western men and, indirectly, between Western men and Japanese men. Moreover, because these relationships arise between teachers and students within an English language teaching institution, they therefore have significance for the construction of professional identities in TESOL.

By turning the spotlight on white Western men's accounts of heterosexuality and gendered subjectivity in Japan, this article begins to address these gaps in research on professional identity in ELT, and aims to contribute more broadly to 
our understanding of masculinity within ELT as a professional practice shaped by the diverse dynamics of gender and ethnicity. In doing so, it speaks to a broader set of challenges to do with the ways in which TESOL teachers negotiate the complex geopolitical context of their work. As K.E. Johnson (2006) observes, contextual positioning has significant implications for teacher education:

Constructing locally appropriate responses to support the preparation and professionalism of L2 teachers ... will entail recognizing how changing socio-political and socioeconomic contexts affect the ways in which L2 teachers are positioned, how they enact their teaching practices, and, most importantly, the kinds of learning environments they are willing and able to create for their L2 students (p. 247).

While this particular study is located in a specific set of contextual circumstances, I believe it speaks more broadly to the transnational nature of ELT, and has significance for the sorts of conversations we have around teacher education and practice. Clearly, further research is needed on masculinity and heterosexuality in TESOL, but I hope this study will encourage others in the field to explore these dynamics and their effects on professional practice.

In the following section, I summarise the key discourses that circulate around Western male teachers and Japanese female learners of English language in Japan, and then introduce the interview study in which participants position themselves in relation to those discourses. I am using the term 'discourses' throughout this paper in the Foucauldian sense ${ }^{2}$ to mean "practices which systematically form the objects of which they speak" (Foucault, 1972, p. 49).

\footnotetext{
${ }^{2}$ See Pennycook (1994) for a comprehensive explanation of the links between Foucauldian 'discourses' as "systems of power/knowledge within which we take up subject positions" (p. 128), and 'discourse' in the linguistic sense of a text, or 'language in use'.
} 
Used in this critical theory tradition, discourses refers to the "finite range of things it is conventional or intelligible to say about any given concerns" within any community (Cameron, 2001 p. 15). When individuals talk about a topic, they draw from these shared resources, and through such individuals' talk, says Cameron (2001, 'reality is 'discursively constructed', made and remade as people talk about things using the 'discourses' they have access to" (p. 15). Within this tradition, 'discourse analysis' - described in more detail in a later section - can be seen as "a method for investigating the 'social voices' available to the people whose talk analysts collect" (p. 15). Central to this form of discourse analysis is a concern with "how social phenomena are named and organized", through "relations of power, the governing of people and the production of subjects or forms of personhood" (Lee \& Petersen, 2011, p. 140).

\section{DISCOURSES OF DESIRE IN JAPANESE ELT}

Several key discourses on gender relations are relevant to an exploration of white Western masculinity and heterosexuality in Japanese contexts of ELT: the first is a discourse of Japanese romantic desire for the West; the second is a discourse of sexual harassment and discrimination; the third is a discourse of masculine transformation from 'zero' to 'hero' in the journey from the West to Japan. These discourses, summarised below, suggest potential subject positions and relationships for Western men, and have significant implications for English language education in Japan, particularly in the eikaiwa industry.

\section{The discourse of romantic Occidental desire}

Recent research on Japanese women's identity has focused on a discourse of desire - akogare - for the West, English language, and Western men. In this 
discourse, Western men are perceived to embody an idealised, romanticised version of the West, offer access to English language learning, and symbolise an enlightened and liberated alternative to traditional gender hierarchies that are seen to persist in Japanese society³ (Bailey, 2006; Kelsky, 2001; Kubota, 2011; Piller \& Takahashi, 2006). Bailey (2006, p. 106) argues that Japanese women's Occidental desires are, in turn, harnessed by an eikaiwa industry that "market[s] the activity of English conversation as an eroticised, consumptive practice" through the pairing of Japanese women students with white male teachers (see, also, Piller \& Takahashi, 2006, for examples of advertising material). This pattern of consumption "produces and reflects the business interests of the eikaiwa industry which commodifies and exploits whiteness and native speakers" by catering to the desires of certain learners for romantic, exotic "pleasure and fantasy" (Kubota, 2011, p. 482) rather than "linguistic skills to increase cultural capital” (p. 480).

\section{The discourse of sexual harassment}

A different line of argument sees Japanese and non-Japanese women as objects of sexism, sexual harassment, and discrimination in the Japanese ELT workplace (McMahill, 1998; Silver, 2010; Simon-Maeda, 2004); and as potentially vulnerable to exploitation by Western men (Kubota, 2008), who are, by implication, cast as potential villains. These conflicting discourses - of women as desiring, agentive subjects, or as potential victims of male pursuit and exploitation - remain unsettled, leaving open the question of whether Western

\footnotetext{
3 Professional and domestic gender hierarchies in Japan, and their deleterious effects on women, have been extensively explored in a wide range of disciplines (see, for example, Charlebois, 2010; Kelsky, 2001; Ma, 1996; Nemoto, 2008) and are reflected in Japan's low rating in international indices of gender equity, such as the UNDP Gender Empowerment Index and the World Economic Forum Global Gender Gap Report.
} 
men are licentious predators or fortunate, willing participants in sexual relationships that arise in the course of their ELT activities in Japan. They also leave unsettled the difficult question of whether sexual relations between teacher and student within the ELT workplace can ever be realised as other-than sexual harassment.

\section{The discourses of Western masculinity in Japan}

The key discourse on white Western men in Japan is one of transformation from an 'average guy' to a desirable 'superhero'. Although this discourse has not been fully explored in research literature, it is clearly depicted in a text from popular culture, based on the comic strip character of 'Charisma Man' (http://www.charismaman.com/). In the comic strip series (Rodney \& Garscadden, 2002, 2010), Charisma Man is initially presented as a slightly built, rather doleful "average guy," employed in Canada as a burger cook, and spurned by Western women as an unworthy "geek." When transported to "planet Japan," however, he is miraculously transformed into a tall, blonde, muscular Adonis, and finds himself surrounded by an adoring mob of petite, pretty Japanese women. However, Charisma Man must continually defend himself against his "archenemy, Western woman," who lurks in the background threatening to unmask this would-be hero. Charisma Man thus presents the reader with contradictory discourses of white Western men in Japan. He is both 'loser', and 'hero': on the one hand, an unqualified poseur, and victim of Western female scorn; but in Japan, also an active agent, an Adonis in sexual pursuit of (willing) Japanese women. Charisma Man thus represents an ironic self-positioning of contemporary Western masculinity which is dependent on, and accountable to, the female gaze. 


\section{THIS STUDY}

The interview data discussed in the following sections is drawn from a broader study of men and women from Australia and North America, and their accounts of teaching in Japan. This article is based on 11 interviews conducted with male participants whose country of origin is Australia, and explores the construction of white Western masculinities within their accounts of English language teaching in conversation schools in Japan. The interviews represent a qualitative case study that aims to illuminate this field of masculinity and heterosexuality in ELT, rather than seeking to represent a wider population (Chapelle \& Duff, 2003).

Interviewees were selected using a snowballing technique described in more detail below. Each interviewee was interviewed once, during a 12 month period in Japan and Australia, either face-to-face or via Skype, and were followed up by email exchanges in which several participants spontaneously expressed a sense of appreciation in having their stories heard. Interviews with three participants (Tim, Joel, and David) were followed up with further email and face-to-face discussions which helped to inform my interpretation of the interview data.

The interviews lasted between 1 and 11/2 hours, were semi-structured according to a set of guiding questions, but were also collaboratively constructed to maximise opportunities for discussion of issues and topics raised by participants (Mann, 2011). Interviewees were first asked to sketch their qualifications and work history, including the reasons for their travel to Japan for work. Interviewees were then asked:

1. Whether they were aware of the Charisma Man phenomenon (that is, Japanese women's purported desire for Western men) 
2. Whether they knew of men who fit the Charisma Man stereotype (and what that type of person was like)

3. Whether they saw themselves as a Charisma Man

In these questions the trope of Charisma Man served merely as a prompt for the men to talk about themselves and their experiences as white Western men working as language teachers in Japan. As such, the prompts function as an 'incitement to discourse' (Foucault, 1978), and a means of eliciting a range of available discursive constructions in relation to this topic.

Each of the men spoke English as their first language, and had at least one university degree; all except for Paul had TESOL qualifications gained either before or during their periods of teaching in Japan. Eight of the eleven interviewees had Japanese wives, four of whom had been either students or staff at the institutions where the men taught. Brief background information on participants is given in the table below; however, the imperative to maintain participant anonymity means this information is necessarily limited.

\begin{tabular}{|c|c|c|}
\hline Pseudonym & $\begin{array}{l}\text { Age of arrival } \\
\text { in Japan }\end{array}$ & Work history in Japan \\
\hline Ben $(F)$ & late $20 \mathrm{~s}$ & $\begin{array}{l}10 \text { years: teacher of English in eikaiwa and high } \\
\text { schools }\end{array}$ \\
\hline Mike (F) & $\operatorname{mid} 30 \mathrm{~s}$ & $\begin{array}{l}3 \text { years: EL teacher of English, then teacher-trainer } \\
\text { and manager in eikaiwa }\end{array}$ \\
\hline Gus (F) & early 20s & 5 years: EL teacher, then a manager in eikaiwa \\
\hline Carl (F) & early 30s & $\begin{array}{l}21 \text { years: EL teacher in Japanese high school; then in } \\
\text { university-level EL teacher education program }\end{array}$ \\
\hline Rob (F) & early 20s & 2 years: EL teacher, then head teacher in eikaiwa \\
\hline Tim (F) & late $20 \mathrm{~s}$ & $\begin{array}{l}22 * \text { years: teacher in vocational college and } \\
\text { university }\end{array}$ \\
\hline Lenny $(S)$ & early 30s & $\begin{array}{l}2.5 \text { years: EL teacher in eikaiwa; then EL teacher in } \\
\text { Japanese high school }\end{array}$ \\
\hline Paul (s) & mid 20s & $\begin{array}{l}5 \text { years: EL teacher then curriculum support in } \\
\text { eikaiwa }\end{array}$ \\
\hline Joel (S) & late teens & 18* years: EL teacher in eikaiwa, then in university \\
\hline David (S) & mid 30s & $\begin{array}{l}11 \text { years: EL teacher in eikaiwa, then in tertiary } \\
\text { institution }\end{array}$ \\
\hline Eddy (s) & mid 20s & $\begin{array}{l}10^{*} \text { years: EL teacher in eikaiwa; now seeking work in } \\
\text { EAP }\end{array}$ \\
\hline
\end{tabular}

* with breaks for return to further study in Australia

$(F)=$ face-to-face interview 
(S) = Skype interview

\section{Discourse analysis approach}

The discourse analysis approach adopted here is situated within a tradition of "Foucauldian discourse studies"4 that explore how "situationally 'provided' discourses shape and guide (but do not determine) what might be said in social settings", and how "social realities" are "built up" through participants' "organization and use of discursive resources and opportunities" (Miller \& Fox, 2004, p. 37). In keeping with this tradition, my analysis focuses on the ways in which spoken language is used to structure a particular social world, give meaning to events, and offer particular subject positions for EFL teachers to take up, or to resist (Cameron, 2001).

My analysis also draws on understandings of gender as a discursive achievement, a "repeated stylization of the body, a set of repeated acts within a highly regulatory frame" (Butler, 1990, p. 32), rather than a fixed, pre-given entity. Men's narratives are taken as discursive practices that produce and project the subject as a particular type of masculine self (Cameron, 2001; Edley, 2001; Speer, 2005), through talk that entails each interviewee's "social positioning of self and other" (Bucholtz \& Hall 2005, p. 586), achieved by indicating dis/identification with relevant discourses, institutions and social categories.

\section{Process of analysis}

Each of the interviews was recorded, transcribed into 275 pages (over 111,000 words) of data, and subjected to an iterative process of analysis

\footnotetext{
${ }^{4}$ For a clear explanation of how Foucauldian discourse analysis compares to, and differs from conversation analysis and ethnomethodology, see Miller and Fox (2004).
} 
"proceeding from more general to more specific observations" (Chapelle \& Duff, 2003). Key phases in the analytic process are described below, and were designed to identify the recurring patterns, discourses, and "social voices" (Cameron, 2001, p.15) that men invoked to explain their lived experience, and to "position themselves [and others] as particular kinds of people" (Pavlenko, 2007, p. 167).

The first phase entailed a close reading of transcripts to identify the ways in which each interviewee positioned himself in relation to 'Charisma Man' as a cultural trope: an immediately available discourse, and a stereotypical construction of, white, Western masculinity in Japan. In these readings, the most common pattern of response could be summarised as something like: "I'm not a Charisma Man, but I know someone who is!" followed by narrative accounts of certain other Western men (teaching colleagues), who were categorised and evaluated as behaving in an unacceptable way. From this pattern of disidentification, a set of unacceptable attributes for the category of 'male English language teacher in Japan' could be identified. As Rapley (2001) notes, this construction of an illustrative 'other' allowed interviewees "to produce themselves, in and through talk, in a 'favourable light', a morally adequate light, ... as a certain type-of-person" (p. 308). Thus, across the collected interviews, participants produced various types of a set of activities and attributes for an unacceptable masculinity (including, for example, lascivious; unprofessional; uninterested in pedagogy), and an alternative, and often opposite, set of 
practices and attributes for themselves, thereby constructing an identity ${ }^{5}$ for an acceptable masculinity in this particular context.

A second phase of analysis was conducted in relation to the discursive categories (of institutions, places, people, objects) introduced by participants in their accounts of the Charisma Man phenomenon. Three primary employment locations were identified: the eikaiwa (a site where all but one of the men had started their Japanese employment), the university system, and the JET ${ }^{6}$ program; and three primary sets of relationships were described: amongst Western men; between Western men and Japanese women; and between Western men and Western women. This yielded a particular characterisation of the eikaiwa industry (for example, as a business with commercial imperatives); and of Japanese women (for example, as active agents, rather than passive victims; and as customers, rather than language learners); of Western women ${ }^{7}$ (for example, as active agents, or as miserable victims); and, to a lesser extent, Japanese men (for example, as profit-focused businessmen, but as undesirable dating partners). I emphasise that these are the interviewees' representations of shared cultural knowledge: from the Foucauldian perspective, they 'systematically form the objects of which they speak' by drawing on the 'social voices' that circulate about these topics within this community.

\footnotetext{
${ }^{5}$ I am following Hall's (1996) use of the word 'identity': "to refer to the meeting point, the point of suture, between on the one hand the discourses and practices which attempt to 'interpellate', speak to us or hail us into place as the social subjects of particular discourses, and on the other hand, the processes which produce subjectivities, which construct us as subjects which can be 'spoken'. Identities are thus "points of temporary attachment to the subject positions which discursive practices construct for us" (pp. 5-6).

${ }^{6}$ The government sponsored JET (Japan Exchange and Teaching) program recruits young university graduates (mostly native English speakers) to Japan to assist with classes taught by Japanese foreign language teachers.

7 Detailed analyses of the interview interactions, and the men's accounts in relation to Western women, are beyond the scope of this article, but will be presented in a forthcoming publication.
} 
A third phase of analysis focused on a key pattern evident in the men's accounts of their relationships. In this reading a recurring issue for the construction of Western masculinity was that of agency: most importantly, whether the men positioned themselves as active agents, making personal choices and professional decisions; or as objects in the decision-making processes of institutions (the eikaiwa) and other actors (Japanese women).

In conjunction with the three phases outlined above, an incremental, iterative process - moving back and forth between interviewing and analysis strengthened the emerging discursive framework. First, a provisional, preliminary set of discursive patterns, categories, and self-positionings was developed from analysis of the first four interviews, and then progressively refined, elaborated, and modified in the light of three subsequent rounds of interviews. At each stage of this process, I received further feedback on the credibility of the discursive framework by presenting analyses at conferences in Australia and Japan (Appleby, 2009a, 2009b, 2010), and interviewing men who came forward in response to these presentations. This iterative process, carried out over several phases of interviewing, analysis and presentation has, I believe, produced a robust analytical result. Further, since this article was first written, the credibility of the identified analytical discourses and categories has been further confirmed by more recent interviews conducted with four more participants. As of November 2011, a total of 19 interviews had been conducted with male participants from the USA, UK, and Australia; and preliminary interviews had also been conducted with 7 female language teachers to explore their views on, and experience of, the same topics. 
Since the achievement of identity is necessarily affected by interactions with others, I acknowledge that my own identity would have influenced the way my participants represented and "perform[ed] their own version of masculinity" (Cameron, 2001, p. 173) for the interviewer-as-audience. How might the interviewees have seen me? As a Caucasian Australian, I share some cultural similarities with my Caucasian Australian colleagues; and as an English language educator, I could be expected to have familiarity with certain aspects of the profession and, perhaps, to be an ally in a business where the value and status of our work is sometimes brought into question (Johnston, 1997; K.E. Johnson, 2006). But in my professional status as a female academic, I also potentially represented a threat to any would-be Charisma Man. Indeed, as the research progressed, I became increasingly aware of the extent to which men made an effort to distance themselves from the more obnoxious characteristics of Charisma Man, and to construct - through the articulation of perceptions and experiences - a version of themselves, and their masculinity, that society (and I) might consider acceptable. While this dynamic certainly shapes what men may have told me about their own experiences, behaviours, and feelings, it also demonstrates the way in which our fluid identities are always formed in social interaction, and in response to perceived opinions held by others (Mann, 2011).

The following discussion of interview data focuses on the men's constructions of and positionings within masculinity. The discussion is organised around the prevailing narrative trajectory the men presented in their interviews: that is, the career path from home country to Japan; initial employment in an eikaiwa; constructions and dilemmas of pedagogical and personal relationships in the context of the eikaiwa; constructions of professional identity in the 
eikaiwa and beyond. In the following sections, I have selected excerpts that seem to most clearly and succinctly illustrate the men's accounts, and demonstrate my analysis of the various discursive positions and categories produced by the participants.

\section{MASCULINITY AND THE SEARCH FOR PROFESSIONAL IDENTITY}

\section{Working in Japan: an embodied ideal of Western masculinity}

The desire for professional status, realised through secure, well-paid work with opportunities for career advancement, was a salient discourse in the men's accounts of leaving Australia in order to pursue English language teaching in Japan. For those with minimal ELT qualifications, like Paul and Lenny, Japanese recruitment campaigns in Australia offered the enticement of relatively well-paid work for native-speakers of English in Japan. For those already qualified as EL teachers in Australia, Japan held the promise of greater job security and an escape from the "dismal" working conditions (David) and high rates of casualisation applicable in a feminised ELT industry in Australia. For men with more experience as EL teachers, Japan held the promise of career progression unavailable in Australia (Carl), or even the possibility to "get out of TEFL [...] and try a corporate job" (Tim) with higher status and salary.

Regardless of their qualifications in ELT, or lack thereof, the most frequent initial site of employment for the men in this study was the Japanese eikaiwa. In their accounts, the men described a particular ideal, or dominant style, of Western masculinity that was valued by the eikaiwa and promoted for commercial ends. This ideal was presented by individual men as a form of 'hegemonic masculinity' (Connell, 1995), an embodied racial stereotype with specific performative characteristics that was preferred within this particular 
professional site, and deployed as a lure for the female Japanese student clientele. As Kubota (2011, p. 477) notes, teachers at eikaiwa schools are still "predominantly white native speakers of English - more often male than female." For Ben, echoing this cultural knowledge, the equation was simple: "predominantly the students were female in the conversation schools, so the teachers were male, they chose male teachers." In Joel's account, this meant teaching in Japanese eikaiwa was "a male dominated thing," so "if you wanted to work in an English conversation school, obviously if you're a white male and you have a pulse, you'd probably get a job." In this context of ELT-as-commercialenterprise, the combination of whiteness, Western origin, and masculinity was perceived as the embodied hegemonic ideal for employment as an EL teacher, a view corroborated by earlier analyses of ELT, and the eikaiwa industry, in Japan (see, for example, McVeigh, 2002; Piller \& Takahashi, 2006).

In the hierarchy of qualities preferred by the eikaiwa, the men asserted that professional TESOL qualifications or experience were of negligible importance. As Paul explained, his own lack of ELT credentials presented no obstacle to his employment within one of the largest eikaiwa chains, whose recruitment campaign in Australia invited prospective employees to "live and work in Japan, no experience necessary." In place of professional qualifications, the eikaiwa provided a routine script for classroom practice: each class had "pretty much exactly the same lesson structure and you're expected to teach in that way. [...] You have to learn those steps". However, with "those steps" under control, Paul found "your personality comes through."

The display of "personality," then, was perceived to be a valued characteristic of the ideal Western EL teacher, and several men described a particular 
performative style that was favoured by the eikaiwa. According to Ben, the eikaiwa "just need someone who is outgoing, someone who's genki [lively] enthusiastic, someone who's young, someone who looks good and someone who is popular with the students." By conforming to these expectations, both Rob and Paul experienced a form of Charisma Man transformation when teaching in Japan:

I became a completely different person to who I'd been before. I'd been very reticent and shy and reserved but suddenly you're almost being an entertainer in a way and becoming more socially adept at managing conversations (Rob).

At work you do have to act like the stereotypical loud bright and happy Westerner kind of thing. [...] It's just part of the company's image. [...] it's a full profit business so we've got to keep the customers satisfied, keep them happy, make them want to come back, that kind of thing (Paul).

The obligation to shape a particular performative style not only served commercial interests, but also provided significant personal and professional benefits. For Paul, who described himself as "a bit of a geek" and "socially awkward" before going to Japan, the requirement to "act" the part of a "stereotypical loud bright happy Westerner" became part of his personal performative repertoire: "I've just sort of learnt a lot about how to talk to people, how to deal with people through that job and I think it's sort of given me a lot of confidence and whatever to talk to people." As a result, he described the eikaiwa experience as "one of the best things to happen to me." In this regard, the hegemonic masculinity particular to the eikaiwa was an ideal with which Paul happily identified.

Alignment with the eikaiwa's embodied performative ideal also afforded the Australian men greater confidence with Japanese women, and enhanced their masculinity by boosting heterosexual success. Paul, for example, confessed his 
social awkwardness meant he "wasn't dating much" in Australia because he "wasn't prime dating material"; but in Japan he had dated Japanese women, one of whom he eventually married. For Ben, the ease with which he could attract the ardent attention of Japanese women students by simply being "polite," "friendly," and "expressive" also contrasted with the difficulty he had experienced with Western women in Australia, where "you would often try harder and harder and sometimes be unsuccessful [...] some women were aggressive [...] you'd try and make friends with a girl politely and you had to be careful who you chose because it just didn't work." This binary distinction between 'aggressive' Western women and 'polite' Japanese women reflects a pervasive discourse in popular culture and has significant ramifications for intercultural gender politics (see, for example, Kubota, 2008). Despite the benefits they enjoyed, however, Ben and Paul's alignment with a perceived Occidental ideal of Western masculinity also presented significant dilemmas. Indeed, for all the men in this study, such an alignment raised particular problems for the construction of an acceptable masculine professional identity.

\section{CONFLICTING DISCOURSES OF EMBODIMENT, SEXUALITY, AND PROFESSIONALISM}

While the accounts so far indicate some of the advantages the men experienced in their alignment with the hegemonic ideal of Western masculinity in the eikaiwa, all the men in this study spoke at length of the difficulties they faced in negotiating and maintaining an acceptable professional identity as a teacher. Their struggles revolved around three inter-related dilemmas: the commodification of the male body in the eikaiwa; ambiguous policies on teacher- 
student fraternisation; and the regulation of heterosexuality in the teacherstudent relationship.

\section{Commodification of the white Western male body}

Despite the ease of employment and, at least for some, the initial appeal of erotic frisson in the workplace, the men resisted their positioning by the eikaiwa as sexualised lures for female "customers." Eddy, for example, expressed the common complaint that the schools "make a commodity of the teacher" in order "simply to keep the students happy and interested" and thereby "achieve some sort of competitive advantage":

It is in some ways- it's- I don't know, it's kinky, [...] suggestive. You find yourself being sexualised, I guess, by the company. Sex sells, to use an old adage.

Indeed, several men echoed Kubota's (2011) observation that many commercial eikaiwa schools are best described not as educational institutions, but as businesses that packaged white Western men as products to be sold to Japanese female consumers, whose interests lay in an exotic experience and a romantic dream, rather than acquiring the English language. In Mike's words:

Those conversation schools, they're really just money-making machines, you know, the students, mostly young women, get sold a kind of a dream, you know, come and learn English and you'll have a better chance of meeting a Western boyfriend and becoming someone that you see on TV or in the movies. I think that was even part of the sales pitch.

Given this 'sales pitch', Eddy found classroom interactions could be easily misinterpreted by students accustomed to a different set of interpersonal "taboos [and] unwritten limits" that might govern interaction between Japanese:

In an English teaching classroom I suppose that, you know, [students] don't have that understanding of the unwritten rules and so it becomes a bit more laissez-faire [...] I guess they feel liberated by that [...] it's 
probably much more of a level playing field [between teacher and student], or more touchy feely. [...] If they're used to a certain interaction with a [Japanese] teacher, and this is suddenly changed to this very open, sort of, you know, freestyle conversation style, then perhaps that girl, that women might think that the teacher is interested, I don't know, it can be misinterpreted like that.

Likewise, some students' intentions towards teachers were viewed with some suspicion, as routine questions about marital status could be misconstrued, and pedagogical identities became confused, as Joel explained:

Joel: I didn't think that many people came there for learning. It was just a very- like a meat market I suppose. You come in, 'hello, what's your name?', 'are you married?', obviously that was for the young ones, 'do you have a girlfriend?' [...] This idea that Charisma Man was a sort of predator on unsuspecting Japanese women, to my mind, is not the way I remember it. I'd say that men in some ways were very sort of sexualised by the women, if that makes sense, but it's like 'I want to find a foreign boyfriend'.

As a consequence, Joel said "I never really thought of the students as students, because they're not, they're customers" who were quite explicit in the expression of their desires for male teachers as products: "I'd say that men in some ways were very sort of sexualised by the women [...] I just felt very commodified and sort of- it was all just a bit meaningless [...] in many ways you feel like a whore I suppose being involved in it. So it's like [being] glorified hostess." In this confusion, Mike observed that some "Western guys thought that [...] they were Lotharios, [but] in fact they were the ones that were being stuck on the belt of these women." In this sense, Japanese women's desire could present something of a threat to masculine agency, authenticity, individualism and self-awareness. The men's accounts suggested that to be seen as an object of the Occidental gaze, a decorative accessory, or a victim of aggressive and indiscriminate sexual conquest, was damaging to one's identity as properly masculine. 


\section{Ambiguous policies on fraternisation}

Joel's reference to his role as a "glorified hostess" for female "customers" suggests the eikaiwa presented an ambiguous space where, for some men, educational activities conflicted with the sociosexual liaison implicitly encouraged between teachers and students. As Lenny explained, this ambiguity was evident in divergent eikaiwa policies on "fraternisation":

[One eikaiwa chain] had a very strict policy of you must not socialise with the students [...] but the people I was working with at the time [in another chain], they were quite keen about it, just saying yes, socialise with these students because in the end the students think, 'oh well, it's almost like another lesson'.

These mixed messages about the permission granted to teachers blurred the boundary between professional and personal domains, but were ultimately seen to serve the commercial interests of the eikaiwa, for whom teacher-student relationships were only perceived as a problem if a student-customer complained. In other words, teacher-student sex was constructed as a commercial consideration, rather than a moral issue. Individual men thus faced the challenge of negotiating a fine line between frisson and infraction. Overstepping that line caused problems for the eikaiwa, as Paul noted:

There are still problems with teachers usually at school parties and stuff where alcohol is involved. Some teacher would try to proposition a student who's really not interested, and then that complaint goes to the school, and then to the head office, and then someone has to go out with the fire extinguisher and get rid of that problem.

Employing teachers who had serial relationships with students, whether or not they were the subject of a student complaint, then became a management problem. From a manager's point of view, Mike explained: 
A lot of these guys would date a lot of different girls in a serial way, so theyou know the ex-s would be a problem on the schedule. You'd be trying to do the scheduling and you know, 'oh he used to go out with her', although you can't really talk about it, you can't really ask, you can't be transparent about it but you know it was sort of an open secret so it would be an issue in planning classes.

In the confusion of identities here, it seemed a blurry line of professional probity may sometimes be crossed, necessitating corporate damage control; but the boundary was itself obscure, and transgressions only marked as such when a customer was likely to complain. In order to avoid the challenge of negotiating this fine line, several men reported their efforts to erect and maintain a clearer division between professional and personal domains. Mike, for example, deliberately ignored flirtatious approaches from students: "I had this thing about 'you don't talk to students'." Even Paul, who revelled in the interpersonal engagements encouraged by the eikaiwa, insisted: "I didn't want to date a student. I've heard lots of stories about guys dating their students. [...] I just wanted to keep the work here and the personal over here."

\section{Regulation of heterosexuality}

Although dating students was presented as a common occurrence amongst eikaiwa colleagues, the men's responses to these relationships varied. While Mike and Paul's approach reflected practical considerations, other men expressed outrage and repugnance at accounts of teacher-student relationships. Some regarded the expression of sexuality between young adult teachers and students as 'natural' and 'healthy'; but even those who found the admiration of Japanese female students was affirming set clear moral limits in regard to acceptable behaviour, and condemned relationships involving excessive promiscuity, exploitation, and bragging. And in their accounts, each of the men 
relayed disparaging stories of Western male teachers who fit the Charisma Man image of an illegitimate and undeserving, yet rampant, heterosexuality. Each of the interviewees told stories of teachers like Eddy's unattractive colleague. Eddie described him as

Quite a skinny, small guy [who] turned into a bit of a Romeo or a bit of a gigolo [...] seeing every woman that he came across as a potential partner [...] he just got the impression from living here, through his experiences as an English teacher [...] he just thought every woman who spoke to him in English wanted to go to bed with him.

Yet each of the interviewees distanced themselves physically and discursively from this stereotype of unacceptable heterosexual masculinity, as did Eddy:

I distanced myself from anyone who I thought was like that, because I thought it was just complete exploitation, because he was having relationships with a lot of his students at the same time. I mean it was just disgusting. I was appalled by it. You know I suppose I'm a bit of an idealist. I mean I believe a lot of- in sort of the ethics of being a teacher, and this guy didn't really see it that way.

Even men who had themselves enjoyed sexual relationships with students presented stories that served to distance their own experiences from those of colleagues who fit the toxic Charisma Man stereotype. In this way, the Charisma Man trope served the function of an abject Other (Butler, 1995), a symbolic repository for an unacceptable macho heterosexuality. Ben, for example, observed that "there were some guys who just- it was a contest, how many girls could you sleep with [...] I met some guys who were just ... animals." Ben's colleague, Jamie, was described by him as one such teacher: "23 years old, blonde hair blue eyes, um good physique, and um he had the patter right down pat." For Ben, Jamie's transgression was not only that he was promiscuous, but that his promiscuity was duplicitous, and a topic of competitive boasting: 
His catch phrase was 'variety is good', and he was a good-looking guy, and he was a very smooth talker, and he could have had women in any country any time but he took advantage of it and it was so unpleasant, cos you'd see these women, they were often students, and they were just, distraught, just completely distraught, [...] cos he'd sleep with them, and then just- promise them the world and then, find the next one [...] it was just one after the other, it was ridiculous, he'd boast about it [...] when we got together for drinks and so on in the evening, whatever um, and ah it was just ... ugly.

As in the Valentine's Day anecdote, the implicit competitive relationship amongst the men - a theme much discussed in scholarly analyses of masculine identity (see, for example, Cameron, 2005; Connell, 1995) - is central to the construction of successful masculinity, and yet Ben explicitly distanced himself from Jamie's macho excess by describing his own behaviour towards Japanese female students as utterly ordinary and restrained, "polite" and "friendly" "in a normal way, nothing over the top." Although "once or twice there were a lot of tears involved" on the part of the female students, these relationships were primarily construed in terms of mutual agency and innocent fun, as we have seen in the Valentine's Day game.

\section{Compromised professionalism}

Since those who fit the Charisma Man stereotype were described as demonstrating an excessive, embodied expression of rampant heterosexuality, an important strategy for presenting an alternative, counter-hegemonic masculinity was evident in interviewees' alignment with teaching as a rational, professional pursuit. In their accounts, the men articulated a commitment to pedagogical practice and, by implication, an identification with educational work as appropriately disembodied and "sexless" (Gallop, 1995, p. 83).

Given the conditions of the eikaiwa, however, identifying with a discourse of ELT as a professional, pedagogical practice presented several challenges. As Paul 
had found in the recruitment process, "no experience necessary" was a phrase that characterised eikaiwa employment: embodied identity (white, native speaker, male) was favoured at the expense of ELT qualifications. As a result, many of the men complained that their eikaiwa colleagues demonstrated a marked lack of interest in pedagogy. In his job as a teacher trainer, Gus believed that many of the young male recruits were only "in Japan for the girls," not because they "wanted to teach":

It has a great effect on their commitment to teaching and therefore their ability to teach and how their classes went, you know, how they treat the students in class and inappropriate things that they may or may not do. [...] Japan English conversation schools are not known for having real teachers as such because [...] most people who go to these schools are people who are there for other reasons [...] if you're into teaching, then it's not quite the community [where] people are into teaching.

Emphasising their own interest in teaching - rather than in Japanese women then became a point of contrast for individual men. In the eikaiwa, Mike found that "you could walk into any school and immediately you're exotic because you're interested in the pedagogy, whereas other teachers are more interested in drinking, and meeting girls, getting through the classes, you know for them [teaching] was probably quite onerous." If Charisma Man is a teacher who finds his work "onerous," then it was incumbent on men who would distinguish themselves from this type to display their ambitions for career development and devotion to EFL pedagogy. Even Ben distinguished himself as someone who was intrinsically interested in teaching, rather than as someone just using the job as a means of meeting Japanese women: "I really enjoyed teaching [in Japan]. I got a lot out of teaching and I really enjoyed it."

However, although the men attached value to their role as teachers, they claimed that these values were in conflict with the commercial priorities of the 
eikaiwa, where they perceived there was little regard or reward for teacher qualifications and professional expertise. So, while the commercial drive of the eikaiwa meant Western men were in high demand and enjoyed ready job opportunities, those same commercial imperatives and cost-cutting competition resulted in what Joel described as "a low paid crappy job" with "crappy conditions, contract work, no stability, superannuation." Ironically, Joel observed that these conditions were so grim that the Japanese ELT staff in his eikaiwa were almost all women: for “the Japanese men, you couldn't sustain it, or support a family on any eikaiwa type wage." Such conditions, combined with the generally poor educational reputation, meant that for most participants a certain sense of emasculating shame eventually attached to classroom teaching in the commercial eikaiwa industry. Eddy, for example, described eikaiwa employment as "the McDonalds of English teaching," and Paul spoke of the "professional snobbery" amongst Western workers in Japan, where English language teaching was seen not as a "real job," but rather as an occupation for Western men who are unqualified to do anything else. Not surprisingly, then, David claimed that his initial "objective when I came to Japan [was] to get out of [the eikaiwa], it's the bottom of the rung [...] I didn't really want to be at the bottom of the pile in the English teaching world in Japan."

From the men's perspective, it seemed the only way to attain professional self respect was to escape the compromised, sexualised site of the eikaiwa classroom, by moving into curriculum development (as did Eddy and Paul), climbing the eikaiwa corporate ladder (as did Mike) or, more commonly, finding work in a more prestigious institution, such as a university (as did Joel, Carl, and Tim). Men

\footnotetext{
${ }^{8}$ Kubota (2011) notes that Japanese women are economically positioned even below the Caucasian English language teachers, a factor that was not mentioned by the male interviewees.
} 
who stayed in, or returned to, the eikaiwa system expressed both humiliation and disillusionment. For Ben, a decade of casual eikaiwa appointments, and a failed attempt to launch his own EFL business, had resulted in a sense of resignation and disenchantment. When asked if being a male teacher in Japan had been beneficial to his teaching career, Ben replied:

There's no such thing as a career, in that sense, in Japan, um, it's not a career, it's a job, um, [employers] don't expect you to stay very long, they don't want you to stay very long [...] you were a novelty value.

Ben believed that if he had made the right connections, he could have entered the university sector, where he assumed it was possible to "do interesting teaching." But with that door closed, he became "tired of Japan, after so many years" and decided to once again "try out my luck in Australia."

The specific challenges the men faced in returning to Australia or entering the Japanese university sector are beyond the scope of this article. Suffice it to say that their difficulties in pursuing professional success in ELT were not easily resolved by moving to a new educational sector, or by changing countries. In both these moves, gender and sexuality continued to feature as factors in the men's construction of acceptable professional and personal identities.

\section{CONCLUSION}

In this article I have argued that masculinity and heterosexuality have remained unmarked categories in studies of English language teacher identity, despite recent interest in gender and sexuality more broadly within the field of TESOL research. As a first step towards addressing this gap, I have focused on men's constructions of white Western masculinity and heterosexuality in Japanese commercial English language schools: a key international site for the 
employment of native-speaker EFL teachers, and a rich epistemological site in which gender, sexuality and intercultural desire are salient in the constitution of teacher-learner relationships.

This study highlights certain key discourses that pertain to constructions of white Western masculinity and heterosexuality amongst language teachers in Japan. First is a discourse of professional desire in which the men's accounts of overseas experience was underpinned, at least in part, by a drive to exercise professional agency, freed from perceptions of a feminised industry in their home country. However, the men's desire to construct a professional masculine identity was disturbed by the complex web of discourses that came into play in the eikaiwa industry. Here, an embodied hegemonic masculinity was identified: an extroverted and eroticised, white, Western ideal for male teachers, produced as a commodity for Japanese customer-students. In these sites, Western male embodiment initially appeared as a professional advantage, offering easy access to employment and personal adoration. Yet the blurring of commercial, pedagogical, and romantic discourses in this occupational space meant that standards of acceptability for Western masculinity and heterosexuality were never settled: what remained was a field of possibilities for male teachers to negotiate. In this ambiguous commercial-educational space, identities of teacher and student, male and female, customer and product, agent and object, prey and victim emerged and overlapped, and the men struggled to fulfil their professional desires while simultaneously fashioning a 'morally adequate', yet successfully heterosexual, masculine self.

Notions of unacceptable masculinity were defined through accounts of hypersexual behaviour amongst colleagues who failed to perform according to 
the "norms of 'professional' comportment [that] entail repression of the body's physicality and expressiveness" (Young, 1990, p. 139). In distancing themselves from this 'Charisma Man' behaviour, interviewees asserted their devotion to pedagogy as a rational, disembodied pursuit, and a cornerstone of professionalism. Yet this professional ideal was perceived to be in conflict with the commercial priorities of an eikaiwa industry where an embodied romantic and sexual allure were said to be implicitly encouraged. Although many of the interviewees were selected by employers for promotion, perhaps in recognition of their commitment to ethical professional standards, they each faced significant limits in their capacity to produce an agentive, professional self, operating successfully in a transcultural domain. They continued to occupy the political category marked by their white, native-speaker masculinity, and although belonging to this category offered certain privileges, these privileges were provisional and contradictory.

In the accounts of these men, excessive embodiment eventually became a burden, and then an impediment to the attainment of a masculine professional identity released from the constraints of embodied physicality. Ironically, in the long run, it was the value placed on the white masculine body, at the expense of pedagogical qualifications and expertise, that constrained the professional aspirations of the male teachers.

These multiple discourses of masculinity, and the ways in which individual men respond to them, affect more broadly the ways in which English language teaching is conceived internationally as a professional or commercial activity that serves diverse personal, institutional, and economic interests. Given the scale of ELT as a global industry, it seems timely that scholarly conversations 
about gender and sexuality as dynamic aspects of professional identity be extended to include such experiential accounts and thoughtful consideration of masculinity and heterosexuality as integral to professional practice in TESOL. 


\section{REFERENCES}

Appleby, R. (2009a, July). Charisma Man: Discourses of desire and Western men in Japan. Paper presented at the $2^{\text {nd }}$ International Discourses and Cultural Practices Conference, Sydney, Australia.

Appleby, R. (2009b, November). Reflections of Charisma Man. Paper presented at the $35^{\text {th }}$ Annual JALT Conference, Shizuoka, Japan.

Appleby, R. (2010, September). An acceptable masculinity: White men talk about heterosexual relationships in Japan. Paper presented at the $6^{\text {th }}$ International Gender and Language Association Conference, Tokyo, Japan.

Bailey, K. (2006). Marketing the eikaiwa wonderland: Ideology, akogare, and gender alterity in English conversation school advertising in Japan. Environment and Planning D: Society and Space, 24, 105-130.

Bailey, K. (2007). Akogare, ideology, and 'Charisma Man’ mythology: Reflections on ethnographic research in English language schools in Japan. Gender, Place and Culture, 15, 585-608.

Bucholtz, M. \& Hall, K. (2005). Identity and interaction: A sociocultural linguistic Approach. Discourse Studies, 7, 585-614.

Butler, J. (1990). Gender trouble: Feminism and the subversion of identity. New York: Routledge.

Butler, J. (1995). 'Melancholy gender / refused identification'. In M. Berger, B. Wallis \& S. Watson (Eds.), Constructing masculinities (pp. 21-36). London and New York: Routledge.

Cameron, D. (2001). Working with spoken discourse. London: Sage.

Cameron, D. (2005). Language, gender, and sexuality: Current issues and new Directions. Applied Linguistics, 26, 482-502. 
Cameron, D. \& Kulick, D. (2003). Language and sexuality. Cambridge, UK: Cambridge University Press.

Connell, R.W. (1995). Masculinities. Oxford: Polity Press; St Leonards, NSW: Allen \& Unwin.

Chapelle, C.A. \& Duff, P. (2003). Some guidelines for conducting quantitative and qualitative research in TESOL. TESOL Quarterly, 37, 157-178.

Charlebois, J. (2010). The discursive construction of femininities in the accounts of Japanese women. Discourse Studies 12, 699-714.

Davis, K.A., \& Skilton-Sylvester, E. (2004). Looking back, taking stock, moving forward: Investigating gender in TESOL. TESOL Quarterly, 38, 381-404.

Edley, N. (2001). Analysing masculinity: Interpretive repertoires, ideological dilemmas and subject positions. In M. Wetherell, S. Taylor \& S. J. Yates (Eds), Discourse as data (pp. 189-228). London and Thousand Oaks: Sage.

Foucault, M. (1972). The archeology of knowledge and the discourse on language. Trans. A. M. Sheridan Smith. New York: Harper \& Row.

Foucault, M. (1978). The history of sexuality, Volume I. Trans. R. Hurley. London: Penguin.

Gallop, J. (1995). The teacher's breasts. In J. Gallop (Ed.), Pedagogy: The question of interpretation (pp. 79-89). Bloomington and Indianapolis, IN: Indiana University Press.

Hall, S. (1996). Introduction: Who needs identity? In S. Hall \& P. du Gay (Eds), Questions of cultural identity (pp. 1-17). London: Sage.

Johnston, B. (1997). Do EFL teachers have careers? TESOL Quarterly, 31, 681-712.

Johnson, K.E. (2006). The sociocultural turn and its challenges for second language teacher education. TESOL Quarterly, 40, 235-257. 
Johnson, T.S. (2006). Performing A/sexual teacher: The Cartesian duality in education. Review of Education, Pedagogy, and Cultural Studies, 28, 253-266.

Kelsky, K. (2001). Women on the verge: Japanese women, Western dreams. Durham, NC: Duke University Press.

Kiernan, P. (2010). Narrative identity in English language teaching. Houndmills, UK: Palgrave Macmillan.

Kubota, R. (2008). A critical glance at romance, gender, and language teaching. Essential Teacher, 5, 28-30.

Kubota, R. (2011). Learning a foreign language as leisure and consumption: Enjoyment, desire, and the business of eikaiwa. International Journal of Bilingual Education and Bilingualism, 14, 473-488.

Kubota, R. \& Lin, A. (2006). Race and TESOL: Introduction to concepts and theories. TESOL Quarterly, 40, 471-493.

Lee, A. \& Petersen, A. (2011). Discourse analysis. In B. Somekh \& C. Lewin (Eds), Theory and methods of social research (2nd Ed) (pp. 139-146). London: Sage. Lin, A., Grant, R., Kubota, R., Motha, S., Tinker Sachs, G., Vandrick, S. \& Wong, S. (2004). Women faculty of colour in TESOL: Theorizing our lived experience. TESOL Quarterly, 38, 487-504.

Ma, K. (1996). The modern Madame Butterfly: Fantasy and reality in Japanese cross-cultural relationships. Rutland, VT: Charles Tuttle.

Mann, S. (2011). A critical review of qualitative interviews in applied linguistics. Applied Linguistics, 32, 6-24.

McMahill, C. (1998). A look at women in education and language learning (WELL). The Language Teacher, May. Retrieved December 17, 2010, from http://jalt-publications.org/tlt/files/98/may/mcmahill.html. 
McVeigh, B. (2002). Japanese higher education as myth. New York: M.E. Sharpe.

Miller, G. \& Fox, K. J. (2004). Building bridges: The possibility of analytic dialogue between ethnography, conversation analysis and Foucault. In D. Silverman (Ed.), Qualitative Research: Theory, Method and Practice (pp. 35-55). London: Sage.

Nemoto, K. (2008). Postponed marriage: Exploring women's views of matrimony and work in Japan. Gender \& Society, 22, 219-237.

Pavlenko, A. (2007). Autobiographic narratives as data in applied linguistics. Applied Linguistics, 28, 163-188.

Pennycook, A. (1989). The concept of method, interested knowledge, and the politics of language teaching. TESOL Quarterly, 23, 589-618.

Pennycook, A. (1994). Incommensurable discourses? Applied Linguistics, 15, 115138.

Piller, I. \& Takahashi, K. (2006). A passion for English: Desire and the language market. In A. Pavlenko (Ed.), Languages and emotions of multilingual speakers (pp. 59-83). Clevedon, UK: Multilingual Matters.

Rapley, T. J. (2001). The art(fullness) of open-ended interviewing: Some considerations of analyzing interviews. Qualitative Research, 1, 303-323.

Rodney, L. \& Garscadden, N. (2002). Charisma Man 1998-2002: The complete collection. Tokyo: AKNG Press.

Rodney, L. \& Garscadden, N. (2010). Charisma Man 1998-2002: The even more complete collection. Tokyo: AKNG Press.

Seargeant, P. (2009). The idea of English in Japan. Bristol, UK: Multilingual Matters.

Seargeant, P. (Ed.) (2011). English in Japan in the Era of Globalization, Palgrave 
Macmillan: Houndmills, UK.

Sikes, P. (2006). Scandalous stories and dangerous liaisons: When female pupils and male teachers fall in love. Sex Education, 6, 265-280.

Silver, S. (2010, October 26). Foreigners victims, perpetrators of sekuhara [sexual harassment]. The Japan Times. Retrieved December 17, 2010, from http://search.japantimes.co.jp/cgi-bin/fl20101026zg.html

Simon-Maeda, A. (2004). The complex construction of female identities: Female EFL educators in Japan speak out. TESOL Quarterly, 38, 405-436.

Speer, S. (2005). Gender talk: Feminism, discourse and conversation analysis. London and New York: Routledge.

Young, I.M. (1990). Justice and the politics of difference. Princeton, NJ: Princeton University Press. 